\title{
O Local e o Global na Estrutura da Política Ambiental Internacional: A Construção Social do Acidente Químico Ampliado de Bhopal e da Convenção 174 da Olt*
}

\section{Aletheia de Almeida Machado**}

Em 2004, relembrou-se, em todo o mundo, os vinte anos daquele que se tornou o pior acidente industrial da história. Na noite do dia 2 de dezembro de 1984, na cidade de Bhopal, capital do estado indiano de Madhya Pradesh, um problema de elevação da temperatura e da pressão em um dos reservatórios de gás da fábrica da Union Carbide India Limited (UCIL) - o de número 610 - já era aparente. Pouco depois da meia noite, os superiores do operário responsável pelo turno foram avisados. Ao chegarem à fábrica, cinco toneladas

\footnotetext{
* Artigo recebido em agosto e aprovado para publicação em novembro de 2005.

** Doutoranda em Relações Internacionais pelo Instituto de Relações Internacionais da Pontifícia Universidade Católica (IRI/PUC-Rio), professora da graduação em Relações Internacionais do IRI/PUC-Rio e pesquisadora visitante da Escola Politécnica de Saúde Joaquim Venâncio da Fundação Oswaldo Cruz (Fiocruz).
} 
de emanações do gás isocianato de metila (MIC) já haviam sido lançadas na atmosfera, na região densamente povoada onde se encontrava a planta industrial. O sistema de segurança para impedir o vazamento não funcionou, o que permitiu o espalhamento de uma nuvem tóxica pela zona urbana adjacente de 6.500 hectares. Quarenta toneladas de gás vazaram da fábrica produtora de pesticidas, provocando a morte de 8 mil pessoas nos três dias subseqüentes ao acidente ${ }^{1}$. Mais de 520 mil indivíduos foram expostos aos efeitos dos gases e até hoje, vinte anos após o acidente, 150 mil permanecem cronicamente doentes ${ }^{2}$. Estima-se que 20 mil pessoas já tenham morrido como resultado desse acidente. Muitas, instantaneamente; outras, em decorrência de diagnósticos inadequados, de tratamentos ineficientes e da liberação precária de informações por parte da empresa multinacional envolvida.

Para a política internacional, em termos analíticos, destaca-se, por um lado, o caso de Bhopal por conta de sua gravidade e, sobretudo, de suas peculiaridades políticas e sociais. $\mathrm{O}$ acidente enfocado neste artigo se reveste de carga simbólica considerável, uma vez que a partir do mesmo há uma mudança no enfrentamento do problema dos acidentes químicos ampliados ${ }^{3}$. Longe de ser o único evento dessa natureza a deixar passivos humanos, sociais e ambientais, Bhopal estabelece uma espécie de limite de tolerância da sociedade civil internacional. Passa-se a demandar responsabilidade, por parte da indústria química, sobre seus processos produtivos. Transplantar filiais a países cujas legislações ambientais sejam pouco rígidas não pode mais ser sinônimo de exportação de padrões de poluição e de risco químico às comunidades daqueles países. Tampouco pode significar impunidade. A partir de Bhopal, empresas multinacionais da indústria química começam a ser julgadas, inclusive em seus países-sede, geralmente a quilômetros da tragédia. O legislador passa a impor padrões rígidos para a atuação daquele segmento empresarial. A própria indústria adere a novos padrões de conduta e advoga pelo cumprimento das normas: afinal, quer compartilhar, com todo o setor, os custos da adoção de padrões seguros de produção. 


\section{O Local e o Global na Estrutura da Política}

Ambiental Internacional...

Por outro lado, os desdobramentos desse acidente químico se configuram em oportunidade para um exercício analítico que pode contribuir para a diversificação da agenda de pesquisa das Relações Internacionais (RI) para o meio ambiente. Usualmente, os temas ambientais, em RI, são analisados sob o prisma da literatura de regimes, que, do ponto de vista epistemológico, representa uma retomada das preocupações normativas no campo disciplinar. O problema com aqueles estudos que partem, no entender de Ruggie (1998), de uma ontologia neo-utilitária é que oferecem pouco espaço para a análise aprofundada do papel constitutivo da ação social, dos fatores normativos e ideacionais. Estes, quando examinados a partir daquela ontologia, são vistos de forma instrumental, como constrangimento à ação humana, no processo de consecução de interesses tipicamente materiais e egoístas ${ }^{4}$. A proposta analítica que se apresenta demanda uma visão ampliada sobre o papel das idéias, em que se reconheça o caráter constitutivo da intencionalidade coletiva e das regras. A ausência de uma discussão aprofundada sobre a transformação no ambiente internacional e, conseqüentemente, sobre a capacidade de agir e interagir dos agentes restringe a possibilidade de aplicação dos resultados analíticos, produzidos por neo-liberais institucionalistas.

Por isso, neste trabalho, adota-se a abordagem construtivista das RI para analisar os impactos do acidente químico de Bhopal, privilegiando-se, exatamente, o papel constitutivo da ação humana no processo de construção social da política internacional. O relatório do Programa das Nações Unidas para o Meio Ambiente (PNUMA), intitulado Global Environmental Outlook (GEO-2003, 2003:273), reconhece que os impactos de acidentes ampliados, como esse de Bhopal, muitas vezes transcendem as fronteiras nacionais quer na forma de efeitos ambientais e humanos, quer na forma de ativismo político ou de negociações multilaterais. Esse relatório aponta para o fato de que alguns desses desastres resultaram em normas de caráter voluntário ou mandatório, essencialmente preventivas. Analisar esses impactos, a partir de uma abordagem construtivista, é reconhecer uma dimensão intersubjetiva 
da ação humana. Em consonância com essa opção metodológica, os indivíduos são vistos como seres culturais e autônomos que emprestam significado ao mundo. Da construção dos significados é que surgem os fatos sociais que, por sua vez, dependem da anuência coletiva e das próprias instituições humanas. Em última instância, emprega-se aquela abordagem porque possibilita investigação acurada quanto ao papel da consciência humana na vida internacional. É esta consciência que contribui para a construção de identidades e de interesses dos atores que, por isso, serão analisados em associação com a estrutura ideacional gerada - com a ressalva de que as identidades e os interesses realizam movimento inverso que deve ser observado, influenciando a capacidade e a vontade humanas.

A aplicação da abordagem construtivista concretiza-se com uma proposta de articulação conceitual entre ferramentas analíticas, oferecidas por tal abordagem. De modo geral, pretende-se caracterizar a estrutura de idéias e de normas em que se incruste o acidente ${ }^{5}$; de forma mais específica, almeja-se compreender a maneira pela qual o evento local é construído socialmente, tendo por referência a referida estrutura, e como gera impactos políticos, sociais e normativos em nível global. O argumento que permeia a discussão proposta é o de que eventos locais ambientais podem imprimir marcas sociais e normativas na política internacional. Em Bhopal, não há efeitos ambientais transnacionais, como, por exemplo, o espalhamento de uma nuvem tóxica por países adjacentes ao local do acidente; ainda assim, o evento é alçado à cena internacional, mobilizando amplos setores da sociedade. Isso contribuiu para que se adotasse a opção teórica do construtivismo, uma vez que, usualmente, as abordagens utilitárias tratam da criação de regimes ou da opção pela cooperação quando há problemas comuns a serem combatidos. Explicita-se, assim, o argumento de que se evidenciaram os elementos de globalidade, pertencentes ao evento local, somente porque se verifica um processo de amadurecimento ideacional e normativo que tem como marcos políticos a Conferência das Nações Unidas sobre Meio Ambiente Huma- 
no, realizada em Estocolmo em 1972, e a Conferência das Nações Unidas sobre Meio Ambiente e Desenvolvimento, ocorrida no Rio de Janeiro, em 1992.

A partir da abordagem teórica indicada, este artigo pretende compreender a construção social do acidente ou a transformação de uma ocorrência local em um fato social relevante para a Política Ambiental Internacional (PAI) (Greene, 1997; Hurrel, 1995) ${ }^{6}$. Por que o acidente de Bhopal merece atenção analítica das RI e como foi alçado à agenda de política internacional são perguntas balizadoras da análise proposta. Esta, ao basear-se no construtivismo, intenta diversificar os objetos da PAI e as formas de refletir sobre os mesmos em RI. Assim, emprega-se articulação de conceitos, útil na visualização da estrutura em que está inserido o evento local e, também, do processo de construção social tanto do evento quanto da norma internacional negociada a partir da ocorrência estudada. É essencial ter em mente que nem estrutura, nem fatos sociais podem ser analisados isoladamente; naturalmente, o pressuposto é o de que prevalece a co-constituição entre estruturas e agentes - responsáveis pela construção social do evento - e de que, portanto, não se pode prescindir desses elementos, tampouco dos elos que os unem.

Na primeira parte do artigo, destaca-se o contexto cultural e institucional da cena ambiental como um todo. Sem a apreensão das variações cognitivas e institucionais, do período de 1972 a 1992, relativas, em geral, ao meio ambiente e, mais especificamente, aos acidentes, não seria possível compreender a construção social de Bhopal. Parte-se da afirmativa de que a consciência ambiental amadurecida da sociedade internacional - que passa a repudiar com veemência acidentes como esses - viabiliza a construção social do acidente, por meio da atuação de ativistas políticos e de empreendedores de normas. A materialidade do evento local é transformada e ressaltada pelas idéias referidas ao desenvolvimento sustentável e à segurança química ${ }^{7}$, além de ser conduzida em forma de fato social às relações internacionais por meio daquela atuação que encontra reverberação na socieda- 
de civil cada vez mais preocupada com os temas ambientais. Na segunda parte, evidencia-se o veio condutor do processo de construção social enfocado: a relação local/global na área ambiental. Parte-se de um evento, cujos efeitos e causas imediatas se encontram em um território específico - o acidente ampliado de Bhopal -, mas que ensejam elementos que ultrapassam os interesses locais, adquirindo, posteriormente, uma interface internacional, com a negociação de um instrumento multilateral - a Convenção 174 da Organização Internacional do Trabalho (OIT) para a prevenção de acidentes industriais maiores. É a materialidade do local, transformada pela intersubjetividade dos agentes, influindo na estrutura normativa global. Conclui-se esta parte com a defesa de uma visão mais social do ambiente internacional em que emergiu a norma em questão. Na terceira parte, focaliza-se o papel da OIT como agência líder na discussão da segurança química, internacionalmente, a fim de indicar por que a construção normativa enfocada se verifica no fórum daquela Organização Internacional (OI). Nas observações finais, apresenta-se uma articulação de conceitos do construtivismo como ferramenta útil para a análise de questões ambientais, nas RI, sobretudo ao apontar para fontes normativas que a disciplina poderia desconsiderar por restringirem-se, geograficamente, a um espaço local.

\section{A Estrutura Social da Política Ambiental Internacional: Como se Construíram as Idéias que Colaboraram para Demarcar os Contornos Sociais do Evento Local e que Estão Sintetizadas na Norma Global}

A degradação do meio ambiente faz parte da história da humanida$\mathrm{de}^{8}$. Os efeitos dessa degradação, no entanto, somente adquiriram 


\section{O Local e o Global na Estrutura da Política}

Ambiental Internacional...

uma dimensão global no século XX. Na verdade, o processo de globalização da temática ambiental é marcado, principalmente a partir dos anos 1990, por mudanças fundamentais no Sistema Internacional (SI) - o fim da Guerra Fria e a intensificação da globalização das formas de comunicação e dos meios de transporte, entre outros - e, também, por avanços científicos que permitiram detectar e divulgar, com maior precisão, os efeitos deletérios de séculos de exploração predatória do meio ambiente.

O século XX presenciou não apenas a intensificação da industrialização e a ampliação dos efeitos negativos da exploração dos recursos naturais do planeta. Diante da realidade concreta do aumento da escassez de recursos naturais, dos acidentes industriais ampliados, dos grandes vazamentos de navios, da chuva ácida, do buraco na camada de ozônio, do efeito estufa, da produção de lixo atômico e tóxico, dos desequilíbrios climáticos - entre outros -, verificou-se a edificação de uma consciência ambiental global ou, em termos teóricos, a constituição de uma estrutura de idéias referentes à proteção ambiental. Tal consciência teria surgido paulatinamente, pois foi apenas nas décadas de 1960 e 1970 que a questão "meio ambiente" adquiriu uma dimensão verdadeiramente internacional, tornando-se global à medida que os problemas ambientais se diversificaram e seu impacto se ampliou e se aprofundou. Em termos políticos, é com a Conferência de Estocolmo sobre Meio Ambiente Humano (1972) e com a Conferência das Nações Unidas sobre Meio Ambiente e o Desenvolvimento $(1992)^{9}$ que o tema ambiental se torna, primeiro, internacional e, posteriormente, global, ingressando definitivamente na agenda política dos atores relevantes da cena internacional ${ }^{10}$.

Nesse intervalo de vinte anos, tomaram corpo idéias e instituições que visavam estancar o curso da degradação planetária e que terminaram por compor uma estrutura em que se desenrolam as ações humanas no que se refere ao meio ambiente. Tais considerações iniciais têm especial relevo para este trabalho, na medida em que corroboram 
o argumento proposto de que Bhopal é construído socialmente e alçado à cena internacional, tendo por referência essas idéias e instituições que contribuíram para demarcar os contornos sociais do evento e para gerar uma síntese normativa, por meio dos ativistas políticos e dos empreendedores de normas. Assim, lança-se mão de um certo historicismo para se ter um alcance do processo de constituição dessa estrutura. Essencialmente, é significativo identificar a forma como se deu a entrada do tema ambiental na agenda política e social das Nações Unidas.

Aliás, apesar da reação institucional verificada de início, o ambiente organizacional do Sistema da Organização das Nações Unidas (ONU) teria demonstrado certa reticência quanto à assimilação definitiva do tema à sua agenda. Ricardo Neiva Tavares (1999:95-110), por exemplo, considera que, antes da Conferência de Estocolmo, as questões ambientais teriam recebido tratamento limitado dentro das Nações Unidas. Guido Fernando Silva Soares (2003), por sua vez, vai além ao afirmar que seria inútil buscar, em épocas anteriores à segunda metade do século XX, qualquer manifestação do fenômeno da regulamentação internacional global do meio ambiente. Isso porque, segundo este autor, a deterioração desse meio ambiente, no âmbito das relações internacionais, começa a constar das preocupações dos Estados somente na década de 1960. Para esse autor ainda, os anos que antecederam a Conferência de Estocolmo foram marcados exatamente pela intensificação da degradação ambiental e de seus efeitos, bem como pela ampliação da divulgação de casos emblemáticos e do conseqüente repúdio internacional aos mesmos. Isso é que teria provocado, em última instância, a tomada de posição da ONU. Cabe ressaltar que Soares está preocupado com a "regulação internacional global", com a realidade internacional objetiva da confecção de documentos, de leis ou da ordem normativa propriamente dita. Este trabalho, ao sugerir uma reflexão teoricamente alternativa sobre o tema ambiental, enfatiza, de maneira especial, os acontecimentos de natu- 
O Local e o Global na Estrutura da Política

Ambiental Internacional...

reza política e social e os processos de construção daí decorrentes que influenciaram a atuação de agentes internacionais relevantes e a gênese normativa.

Constatação fundamental para a identificação de uma ampliação da agenda de preocupações ambientais entre as Nações Unidas é o surgimento, na última metade do século $\mathrm{XX}$, de um conjunto considerável de tratados e convenções internacionais multilaterais referentes ao tema e à proliferação de organizações não-governamentais (ONGs) ambientais (Soares, 2003; Litfin, 1999). Segundo Litfin (1999:329-330), em 1969, havia cinqüenta tratados multilaterais cuja temática era o meio ambiente; em 1994, essa quantidade mais que triplicou, alcançando 173. Paralelamente, verificou-se uma explosão no número de ONGs ambientais: de 174, em 1909, para quase 30 mil, em 1993. Tais números seriam evidências de que a agenda ambiental, internacionalmente, sedimentou-se gradativamente. E-o que é ainda mais relevante - que a estrutura política e social em que interagem os agentes envolvidos - Estados, indivíduos, sindicatos, associações - complexificou-se, modificando, conseqüentemente, os processos políticos subseqüentes. Há, sobretudo, indicação de que está em curso uma mudança de mentalidade que desencadeia a mobilização da sociedade civil. Naturalmente, são muitas as influências nesse processo, entre as quais a publicação de livros e artigos paradigmáticos para a tomada de consciência da comunidade internacional quanto à questão ambiental. Trata-se, essencialmente, de dois marcos que incorporaram o espírito da época e, como tal, impulsionaram o surgimento do moderno movimento ambiental: o livro de Rachel Carson, Silent Spring (2002), de 1962, que alertava para o uso indiscriminado de DDT e de outros pesticidas e o artigo "The Tragedy of the Commons", de Garrett Hardin (1968), que propunha um modelo particularmente influente para a explicação das causas da superexploração de recursos ambientais comuns, mesmo diante do reconhecimento das conseqüências danosas de longo prazo dessa su- 
per exploração. Além dessas duas publicações, que obtiveram impacto internacional, é importante lembrar o estudo produzido pelo Clube de Roma sobre o futuro do planeta, intitulado The Limits to Growth (Meadows et alii, 1972), que apontava para um cenário catastrófico, caso não se repensasse os níveis de crescimento econômico e populacional.

Dessa forma, é preciso destacar que a convocação da Conferência de Estocolmo, em 1972, seria fruto desse contexto efervescente de tomada de consciência mundial. O objetivo da Conferência era promover uma abordagem mais coordenada para o tratamento das questões ligadas ao meio ambiente (Greene, 1997:316). Trata-se de um ponto de inflexão fundamental para o desenvolvimento da política ambiental internacional, em geral, e para o exame desse tema pelo Sistema das Nações Unidas (Tavares, 1999:95), em especial. O evento reuniu países desenvolvidos e em desenvolvimento e contou com a participação (limitada) da comunidade científica e, pela primeira vez, de observadores credenciados, de ONGs.

Quanto ao alcance e à magnitude da PAI como um todo, a Conferência de Estocolmo foi o ponto de partida institucional para um processo de amadurecimento ideacional e normativo que se estendeu pelos vinte anos posteriores. Ainda assim, é preciso notar que as ações, engendradas pela ONU na área ambiental, em seguimento às decisões da Conferência de 1972, tiveram significado muito mais simbólico do que prático. Isso porque, por um lado, indicaram claramente o amadurecimento dessa conscientização global quanto ao tema principalmente, dos Estados que sofriam pressões crescentes de suas sociedades -, mas, por outro, não objetivaram o reexame dos padrões de produção, de comércio e de consumo que estão no cerne da questão ambiental. Os acordos do período focalizavam a proteção ambiental e a poluição, deixando de lado as questões mais intimamente relacionadas ao vínculo existente entre meio ambiente, processos produtivos e desenvolvimento. Aquelas ações não buscaram iniciar dis- 


\section{O Local e o Global na Estrutura da Política}

Ambiental Internacional...

cussões quanto à possibilidade, na cena internacional ambiental, de se atribuir aos Estados a responsabilidade por danos ambientais. Além disso, ao PNUMA, criado na reunião de Estocolmo, faltava o peso institucional exigido para a coordenação efetiva das agendas dentro do Sistema da ONU. Se a cooperação internacional na área de fato se intensificou, tornaram-se evidentes, também, várias lacunas institucionais no âmbito das Nações Unidas.

O estabelecimento da Comissão sobre Meio Ambiente e Desenvolvimento, na década de 1980, serviria para sanar os problemas que surgiam com o estreitamento dos laços cooperativos e a intensificação da troca de informações entre os países. As discussões, dentro do Sistema da ONU, sobre as atribuições da Comissão iniciaram-se em 1982. No ano seguinte, o secretário-geral das Nações Unidas encarregou Gro Harlem Brundtland, primeira-ministra da Noruega, de criar e presidir esse órgão especial e independente. A Comissão trataria da proposição de estratégias ambientais de longo prazo, de maneiras de se estabelecer a cooperação entre os países em estágios de desenvolvimento diferentes, bem como de noções comuns sobre a proteção ambiental que ajudassem as nações a tratar, com êxito, de problemas igualmente comuns. A Comissão reuniu-se pela primeira vez em outubro de 1984 (Comissão Mundial sobre Meio Ambiente e Desenvolvimento, 1991). O resultado mais marcante da Comissão foi o lançamento de uma agenda para o setor e a confecção, em 1987, do Relatório Brundtland, intitulado Nosso Futuro Comum, que lançou as bases do conceito de desenvolvimento sustentável.

Foi nesse contexto e em prosseguimento à Convenção de Estocolmo que a Assembléia Geral da ONU se decidiu pela convocação, em dezembro de 1989, da Conferência do Rio de 1992. A cooperação internacional, a partir dos documentos aprovados nesse evento - que contemplavam de forma clara e consolidada a idéia de desenvolvimento sustentável e abrangiam 27 princípios, guias para as ações na área de meio ambiente e desenvolvimento -, mudou de feição, experimen- 
tando um aprimoramento conceitual significativo. Os princípios da Declaração do Rio (1992), como o de "responsabilidades comuns, porém diferenciadas" (Princípio 7) e o da precaução (Princípio 15), passaram a compor as ações cooperativas na área ambiental. A Rio-92 é considerada a maior reunião internacional realizada pela ONU e, principalmente, um marco fundamental para a política internacional, após o fim da Guerra Fria. A partir daquele evento, com a intensificação da constituição de redes de ativistas em torno das ONGs, começam a delinear-se os conceitos de "sustentabilidade" e de "futuridade" "11 que marcarão os acordos ambientais subseqüentes, bem como a própria manifestação de globalidade ambiental.

O conceito de desenvolvimento sustentável havia sido formulado pelo Relatório Bruntland, que, juntamente com o Relatório do Clube de Roma sobre os Limites do Crescimento (1968), a Declaração de Estocolmo (1972), a Declaração do Rio e a Agenda 21 (ambos de 1992), constituem-se nos documentos referenciais de uso e difusão para a consolidação da idéia de desenvolvimento sustentável. Hoje, essa é uma idéia basilar para a política de cooperação internacional, em matéria de meio ambiente, e para o uso racional dos recursos naturais a fim de se evitar a deterioração do capital ecológico mundial. Acima de tudo, o desenvolvimento sustentável implica a inclusão de considerações socioambientais no processo de tomada de decisão tanto político quanto econômico com vistas ao desenvolvimento das nações.

A contribuição das ONGs, tanto no processo preparatório, quanto durante a Rio-92, merece destaque ao indicar a países desenvolvidos e em desenvolvimento a oportunidade de defender a existência de uma correlação entre desenvolvimento e meio ambiente e de demonstrar que os problemas ambientais podem decorrer tanto da pobreza, quanto dos processos de industrialização. Mais que isso, há uma contribuição teórica a se destacar que vai além da conscientização e da mobilização. A partir da atuação desses atores não-estatais, o processo de constru- 


\section{O Local e o Global na Estrutura da Política}

Ambiental Internacional...

ção da estrutura ideacional e normativa, referente à proteção ambiental, é definitivamente selado. Dada a atuação da sociedade civil, a Conferência foi, essencialmente, uma ampla e pragmática negociação, uma troca de compromissos que deixaria de lado o exercício assistencialista da ajuda externa, as reivindicações confrontadoras ou, ainda, a tentativa de reduzir os problemas ambientais a discussões técnicas, retirando-lhes seu caráter político e social.

Em suma, a Conferência de Estocolmo e a Rio-92 são os alicerces (Soares, 2003) desse processo amplo de construção normativa e ideacional. A quantidade de atos internacionais multilaterais, produzidos a partir da Conferência do Rio (acordos de segunda geração), somados àqueles negociados a partir de 1972, permite identificar o aprimoramento de idéias e instituições referentes à proteção ambiental. É esse aprimoramento que confere significado especial ao acidente em Bhopal, que ocorre, exatamente, em um momento de forte efervescência tanto social quanto política. Especificamente, quanto à segurança química, é fundamental notar que esta é abordada de maneira mais explícita como um tema da agenda política das relações internacionais, a partir, também, de 1992. O crescimento dramático da produção e de comércio de substâncias químicas - não acompanhado da adoção de medidas adequadas e suficientemente eficazes de prevenção de acidentes e de promoção da segurança química -, verificado desde a década de 1970, chamou a atenção da sociedade civil e dos Estados para os riscos potenciais embutidos no manuseio dessas substâncias perigosas e dos pesticidas. Antes de 1992, verificou-se intensa mobilização por parte da sociedade civil, em decorrência da ampliação no número de acidentes graves que acompanhou, naturalmente, o crescimento da produção e do comércio. Durante a elaboração do Relatório Brundtland, por exemplo, entre 1984 e 1987, ocorreram casos que ganharam grande repercussão na mídia internacional: o acidente em Bhopal; a explosão de tanques de gás liquefeito na Cidade do México; a explosão do reator nuclear em Cher- 
nobyl; o incêndio de um depósito na Suíça que ocasionou a contaminação do rio Reno com produtos químicos (Comissão Mundial sobre Meio Ambiente e Desenvolvimento, 1991).

A estrutura de idéias referidas à segurança química está, sem dúvida, vinculada à estrutura ideacional ambiental mais ampla. Partindo daqueles princípios e idéias acerca do desenvolvimento sustentável, cabe destacar o processo paralelo de construção institucional, cujo objetivo seria o controle do uso e o manuseio adequado e seguro de substâncias químicas por meio da criação de normas, regras, procedimentos e padrões que acompanhassem a nova realidade. Tal processo pode ser observado quando se evidencia a colaboração, na área de segurança química, entre o PNUMA, a OIT e a Organização Mundial da Saúde (OMS) no Programa Internacional sobre a Segurança Química (PISQ), desenvolvido desde 1980 - no ano seguinte, a OIT aprovou a Convenção e a Recomendação sobre Saúde e Segurança Ocupacional. Também pode ser observado quando se faz referência aos programas da década de 1980, relativos à troca voluntária de informações sobre aquelas substâncias, desenvolvidos pelo PNUMA, em associação com a Organização das Nações Unidas para a Alimentação e a Agricultura (em inglês, Food and Agriculture Organization -FAO). Em 1985, a FAO lançou seu Código de Conduta Internacional para a Distribuição e o Uso de Pesticidas. A solidificação institucional também pôde ser detectada quando o PNUMA, em 1987, estabeleceu as Diretrizes de Londres para a Troca de Informações sobre as Substâncias Químicas no Comércio Internacional. Além disso, houve o debate suscitado na Assembléia Geral da ONU sobre a prevenção do tráfico ilegal de produtos e resíduos tóxicos e perigosos, cujo resultado foi a aprovação da Resolução 44/226 de 22/12/1998.

Quanto à construção conceitual, os Princípios 13 (Responsabilidade), 14 (Duplos Padrões), 15 (da Precaução) e 16 (Poluidor Pagador) da Declaração do Rio (1992) serviram para fortalecer a defesa de pa- 


\section{O Local e o Global na Estrutura da Política}

drões mais sustentáveis para a produção de substâncias químicas, bem como para se advogar o dever da responsabilidade e o direito de compensação a vítimas de acidentes ambientais. Além disso, esse documento admite a noção de notificação e consulta prévia (Princípio 19) em caso de dano de impacto transfronteiriço. A partir da Rio-92, com a adoção da Agenda 21 (1992), determina-se abertamente as diretrizes e os preceitos de política a serem seguidos pelos países, no século XXI, para o "Manejo ecologicamente saudável das substâncias química tóxicas, incluída a prevenção do tráfico internacional ilegal dos produtos tóxicos e perigosos"(Agenda 21, 1992: capítulo 19). Consolida-se, definitivamente, o cabedal conceitual da segurança química, que, por sua vez, define-se como um tema da agenda política internacional. A fim de assegurar aquele manejo ambientalmente saudável, reafirmam-se princípios, tais como os do desenvolvimento sustentável e da melhoria da qualidade de vida. Reconhece-se, sobretudo, o direito (aliás, decorrente do princípio da precaução), tanto das comunidades, quanto dos trabalhadores, de se conhecer os riscos a que estão expostos, bem como o direito das indústrias de proteger informações comerciais confidenciais. O capítulo 19 recomenda a realização de esforços no plano internacional, a fim de se buscarem soluções para dois problemas principais decorrentes da presença de produtos químicos tóxicos no meio ambiente, particularmente nos países em desenvolvimento: (1) a ausência de dados científicos para a avaliação dos riscos inerentes à utilização de tais produtos e (2) a falta de recursos para a análise de risco dos produtos cujos dados científicos já se encontram disponíveis. Defende-se a minimização da produção de resíduos por meio da transformação dos métodos de produção e reciclagem, a promoção do armazenamento seguro dessas substâncias e a necessidade de restringir ou proibir o transporte delas. Recomenda-se, expressamente, que, nos países que recebam suas filiais, as multinacionais não adotem critérios e padrões menos rígidos do que aqueles que prevalecem em seus países-sede. Além disso, defende-se a posição de que os governos não 
devem favorecer a exportação de produtos proibidos ou de uso restrito em território nacional.

Não se pode deixar de identificar a relação de co-constituição entre estrutura e fatos sociais: se a consciência ambiental - de Estados e sociedades - viabiliza e reforça o ativismo político e o empreendedorismo normativo, tornando Bhopal evidente aos olhos do mundo, inquestionavelmente Bhopal contribuiu para aqueles amadurecimento ideacional e aperfeiçoamento conceitual, cuja expressão essencial é o capítulo 19 discutido. Bhopal representa um limite: a sociedade internacional passa a ver como inaceitável a continuidade de acidentes industriais, vitimando um número cada vez maior de pessoas e gerando passivos ambientais incalculáveis para as gerações presentes e futuras, sem, contudo, haver imputação de responsabilidade. A dramaticidade daquela ocorrência e a ausência de regras quanto à responsabilidade, ao direito a compensações ou ao direito a informações acerca dos processos produtivos conclamavam as nações a criar e consolidar normas, regras, procedimentos e princípios que auxiliassem na prevenção de novos acidentes.

Até aqui se tratou da construção normativa e institucional que envolve os Estados como agentes, uma vez que se focalizam os alicerces políticos e normativos da PAI. Mas esse processo de construção, naturalmente, tem uma base ideacional e um contexto social influente. É a consciência ambiental amadurecida da sociedade internacional que viabiliza a construção social dos eventos materiais que compõem aquela estrutura, sobretudo do acidente local que se focaliza. A materialidade do evento local é transformada pelos afetados, pelos ativistas e pela própria indústria, cujas consciências ambientais foram constituídas ao longo do processo de globalização da estrutura de idéias referidas ao desenvolvimento sustentável e à segurança química. Trata-se do que Adler (1997) chama de evolução cognitiva em que fatos sociais ganham relevo na cena internacional. Retornar à internacionalização e à globalização da estrutura ideacional e normati- 
va referida ao meio ambiente - a PAI -, como proposto neste trabalho, é constatar essa evolução cognitiva, atentando para o processo de aprendizagem de novas idéias. Nesse, os decisores adotam novas interpretações da realidade, na medida em que essas interpretações são criadas e introduzidas no sistema político por agentes propagadores de idéias, a partir do aprimoramento da PAI.

Constata-se que os processos de construção social e ideacional analisados são viabilizados por uma dada linguagem, por uma criação e consolidação conceitual, cuja expressão mais significativa é a invenção do desenvolvimento sustentável ou da própria segurança química. A linguagem é, em última instância, um amálgama naqueles processos sociais e, como tal, é considerada ponto de partida da gênese normativa. Novamente, a co-constituição: a linguagem é influenciada pelo mundo em que se vive, determinando-o, igualmente. Nesse sentido, é preciso reconhecer que a linguagem não emerge naturalmente: surge da partilha coletiva de significados. Não é por outra razão que fato social e estrutura ideacional, bem como as dimensões local e global são indissociáveis porque mutuamente constitutivas.

Na seção seguinte, tendo em mente essa evolução cognitiva e ideacional, base da estrutura destacada, bem como a linguagem utilizada por empreendedores de norma, analisa-se a construção social do acidente. Parte-se do pressuposto de que é esse contexto internacional mais social, em que se verifica o amadurecimento de uma consciência ambiental e da própria PAI, que conduz o acidente do âmbito local ao global.

\section{A Relação Local/Global e o Processo de Construção Social do Acidente Químico Ampliado de Bhopal}

O ano de 1984 delineou-se, na verdade, como um ano de tragédia para a segurança química em todo o mundo. Para David Weir e Mar- 
tin Abraham (1985:6), é o ano em que, em muitos países em desenvolvimento, começa a tomar forma um ciclo "Bhopal sem fim". Por exemplo, em fevereiro, explosões e incêndio no gasoduto da Petrobras, ocasionados por vazamento de gás, vitimaram, aproximadamente, quinhentas pessoas na Vila Socó, em Cubatão, São Paulo, Brasil. Na verdade, não se sabe exatamente o número total de vítimas. Muitos dos corpos foram dizimados ou não puderam ser identificados por falta de documentos. Tratava-se, aliás, de um assentamento clandestino. A questão é que o "Bhopal brasileiro" não só não gerou efeitos normativos nacionais ou internacionais, como também não resultou em indenizações. Além disso, as vítimas foram tidas como os únicos culpados. Em novembro, na Cidade do México, outro evento sobre o qual se disse que o "céu pegou fogo". Um vazamento de gás liquefeito de petróleo, em um dos tanques de uma refinaria, provocou sucessivas explosões, ocasionando outras quinhentas mortes e ferindo 4 mil pessoas. Em dezembro, Bhopal. Nem todo evento local, no entanto, gera impactos globais. Carlos Freitas et alii (2000:28), ao citarem análise dos acidentes registrados na base de dados Major Hazard Incident Data Service (MHIDAS), no período de 1981 a 1986, revelam que mais de 1.400 acidentes químicos ampliados ocorreram em todo o mundo, o que revela a multiplicidade e a globalidade do problema.

Como recorrer à disciplina de RI para analisar problemas locais como esses? Aparentemente, tais problemas não seriam enfocados como uma preocupação. Concretamente, no entanto, o contexto internacional, interligado e interdependente, não apenas comporta eventos dessa natureza, como os ressalta e lhes confere importância crescente e global. É certo que a maioria dos eventos ou catástrofes ambientais constitui realidade transfronteiriça. É igualmente certo, entretanto, que há aqueles acidentes industriais ambientais que mesmo tendo causas e gerando efeitos imediatos no território de um único Estado - abrangem elementos internacionais relevantes, que 


\section{O Local e o Global na Estrutura da Política}

Ambiental Internacional...

ultrapassam os interesses locais, adquirindo, dessa forma, interesse geral e, às vezes, universal. Aliás, é exatamente pelo fato de o mundo apresentar-se cada vez mais interligado que eventos locais, como os acidentes, ganham relevo na contemporaneidade. Eventos aparentemente localizados não podem ser tratados como assunto doméstico exatamente porque o meio ambiente é uma realidade sem fronteiras. Além disso, há vínculos dos acidentes com a economia global - uma vez que resultam de atividades econômicas de grandes corporações e com a própria sociedade civil - porque seus efeitos provocam a mobilização de amplos setores de sociedades locais e nacionais, em defesa dos indivíduos afetados.

Veja-se, por exemplo, o caso do acidente ocorrido na cidade de Seveso, no norte da Itália, em 1976, em que a fusão da válvula de segurança de um reator químico da fábrica Icmesa provocou um vazamento de dioxina. Uma nuvem tóxica cobriu Seveso e outras quatro municipalidades da região lombarda do país, estendendo-se por 1.970 hectares. Este acidente e seus desdobramentos em termos de contaminação ambiental e lesões humanas ocasionaram a negociação e a aprovação de uma norma regional, no âmbito da União Européia. A chamada Diretiva de Seveso é considerada um modelo de norma de prevenção de acidentes químicos. Seveso, assim como Bhopal, guarda traços de globalidade essenciais, o que assegura um impacto normativo a esses acidentes.

É fundamental observar que processos de construção normativa não são consequiências imediatas de cada um dos acidentes. Seveso e Bhopal são, na verdade, casos-síntese que desencadearam, em torno de si, extensa e intensa mobilização da sociedade. Devido às características do processo de industrialização mundial, até a década de 1970, constata-se que a maior incidência de acidentes se verificava nos países ditos industrializados. A partir dos anos 1980, as maiores ocorrências passam a ser observadas nos países desenvolvidos. Por um lado, o aperfeiçoamento dos processos produtivos, de transporte 
e de armazenagem, associados à mobilização social e à aprovação de leis rígidas, nos países em desenvolvimento, ocasiona a exportação de padrões de poluição aos países que iniciam a promoção de seus processos de desenvolvimento. A evidência dessas transformações ocasionou os debates que contribuíram para reforçar a inclusão dos Princípios das Responsabilidades Comuns porém Diferenciadas, do Poluidor Pagador e da Precaução, na Declaração do Rio (1992).

Na tentativa de evitar "novos Bhopais" e na esteira daquele processo de construção ideacional iniciado em Estocolmo, há mobilizações, em todo o mundo, o que permite refletir sobre o próprio processo de construção social do acidente de Bhopal. No momento em que, por meio da imprensa, tomou-se conhecimento das dimensões ampliadas do acidente indiano e, posteriormente, das lacunas normativas domésticas e internacionais acerca da possibilidade de imputar responsabilidades e garantir indenizações às vítimas, o acidente não mais se restringiu às dimensões locais. A principal discussão, decorrente do evento, referiu-se ao "foro adequado" para lidar com as questões de culpabilidade e de compensações. Quem representaria as vítimas? Onde julgar a Ucil? Em seu país-sede ou no local da tragédia em que se encontravam as vítimas e o passivo ambiental? Essas indagações remeteram, imediatamente após o acidente, a um problema evidente de soberania: para que o governo indiano, como a parte demandante, conseguisse que o caso Bhopal fosse julgado em corte estrangeira, seria necessário que persuadisse essa corte de que a jurisdição da Índia era incapaz de sanar os litígios, que se assomavam em seu território, de cidadãos contra uma empresa norte-americana. Aliás, analiticamente, esse é apenas um dos problemas de soberania que o acidente de Bhopal, com suas quase 3 mil mortes instantâneas, suscita $^{12}$.

A partir da constatação da existência de um lapso institucional e normativo, há uma intensificação clara do ativismo político em torno do caso. Se, por um lado, já havia indícios da relevância internacional 


\section{O Local e o Global na Estrutura da Política}

Ambiental Internacional...

daquele acidente local, dado o envolvimento de elementos políticos fundamentais, como o exercício de atividades econômico-comerciais de uma empresa multinacional em um país em desenvolvimento, a transferência de atividades produtivas perigosas para determinado país a fim de abandonar os padrões rígidos de vigilância e de segurança, verificados nos países de onde se derivam os processos globais de industrialização, e a mobilização de organismos internacionais para o tratamento da segurança química em seus foros; por outro, a incapacidade de um Estado nacional prevenir a tragédia e, posteriormente, defender os direitos de seus cidadãos teve o efeito de precipitar as ações de redes transnacionais de defesa e de empreendedores de normas (Keck e Sikkink, 1998; Finnemore e Sikkink, 1998). É possível citar a atuação de diversos atores internacionais, como a International Organization of Consumers Unions (IOCU) e a International Confederation of Free Trade Unions (ICFTU); de agentes indianos, como a Drug Action Network, o Medico Friend Circle, a Afogya Dakshatha Mandal, o Delhi Science Forum, Eklavya, Kishore Bharathi, Lok Vignam Sangatana e Karnata Rajya Parishath; e de grupos nacionais que, a partir do caso Bhopal, passaram a se preocupar mais de perto com a situação do setor químico em seus países, como a Australian Consumers Association, a US National Wildlife Federation (NWF), o Worker's Policy Project e o Highlander Center ${ }^{13}$.

Constata-se a constituição do que Margaret Keck e Kathryn Sikkink (1998) denominaram de padrão bumerangue de influência. As associações da sociedade civil locais contornaram as fronteiras do Estado nacional, procurando diretamente, no ambiente internacional, aliados ou vítimas em potencial que pudessem pressionar aquele Estado, de fora para dentro de suas fronteiras. Trata-se de uma flexibilização da noção tradicional de soberania estatal, expressa na recanalização da relação entre indivíduos, Estado e Sistema Internacional (SI). Uma das formas de contornar as fronteiras nacionais, no caso de 
Bhopal, foi a realização de campanhas em que o empreendedor político, cujas ações compunham aquela rede de defesa, teve papel fundamental.

Cabe refletir sobre a forma como essas campanhas rearticulam as dimensões global e local, flexibilizando a noção tradicional de soberania e criando espaços políticos complexos por meio dos quais novas formas de autoridade emergem (Shaw, 2004). Quando discute a interrelação entre a política ambiental global e a local, no caso das áreas de proteção de florestas canadenses, Karena Shaw (idem) parte da delimitação de uma estratégia de campanha dos grupos de ativistas que passaram a se ocupar da defesa daquelas áreas. O objetivo, no caso em questão, é mudar as concepções do mercado, das grandes empresas compradoras de papel e celulose. Almeja-se, sobretudo, tornar inaceitável o consumo de produtos advindos de florestas antigas ou ameaçadas de extinção. No caso de Bhopal, não havia um grupo-líder ou uma estratégia claramente definida. Havia uma diversidade de ações que visavam modificar os padrões da indústria química, principalmente por meio da conscientização da sociedade internacional quanto aos riscos associados aos processos produtivos daquele segmento da indústria.

Outro Bhopal, em qualquer outro lugar, não seria mais aceitável. É a linguagem dos afetados e dos ativistas, expressão da evolução cognitiva apontada anteriormente, que se articula nas campanhas e que traz à tona a questão da responsabilidade corporativa, do direito à informação, da necessidade de se garantir padrões seguros no manejo das substâncias químicas, do imperativo de se proibir a exportação de padrões de poluição aos países em via de desenvolvimento, da necessidade de se submeterem as empresas multinacionais ao direito internacional, do direito das vítimas a indenizações adequadas. Os novos conceitos que surgem desse processo de construção social são uma síntese da norma aprovada e, como tal, passam a compor aquela es- 


\section{O Local e o Global na Estrutura da Política}

Ambiental Internacional...

trutura ideacional referente à proteção ambiental, estrutura esta que, em primeiro lugar, possibilitou essa emergência conceitual.

A esse respeito, a mobilização gerada, a partir do evento indiano, teve todos os elementos das táticas de campanha (Keck e Sikkink, 1998) que serviram à transformação daquele acidente local em um fato social de relevo para a política ambiental internacional. Esses elementos incluem políticas de informação, de criação de símbolos, de responsabilidade e de poder. Assim, realizaram-se congressos e reuniões de expressão mundial, mobilizações em frente às instalações da Union Carbide Corporation (UCC), campanhas pelo boicote aos produtos dessa empresa multinacional - como as baterias Eveready e os pesticidas Sevin e Temik -, pressão sobre os organismos internacionais - como a ONU e a OIT - para aprovação de resoluções com vistas à promoção de medidas preventivas. Instituíram-se redes de defesa transnacional, relacionadas à tragédia, entre as quais aquela intitulada "No-More-Bhopal Network". Criou-se, ainda, um dia especial em homenagem às vítimas do acidente -3 de dezembro. Este dia deveria ser marcado por conferências; seminários para a disseminação de informações e promoção de diálogo entre o setor produtivo, governos e a sociedade civil; alertas sobre outros casos potenciais; pressão sobre a UCC e outras empresas multinacionais do setor para que publicassem informações acerca dos riscos associados as suas atividades; e campanhas contra a exportação de tecnologias perigosas aos países em desenvolvimento. A partir de então, o dia 3 de dezembro ficou conhecido como o "Dia de Bhopal" ou, mais recentemente, com a realização da Conferência Mundial das Nações Unidas sobre Desenvolvimento Sustentável (ocorrida em Johannesburgo em 2002) a Rio+10 -, como o Dia Internacional de Ação contra o Crime Corporativo. Em 2003, foram cinqüenta mobilizações, em dezesseis países, no âmbito da Campanha Internacional pela Justiça em Bhopal, organizada por uma coalizão de ativistas. No Brasil, em 2004, o Grupo de Estudos Tripartite da Convenção 174 da OIT promoveu na- 
quele dia eventos em Brasília, Porto Alegre, Rio de Janeiro, Salvador e São Paulo, em memória aos vinte anos do acidente e como forma de reflexão sobre o compromisso de todos os setores da sociedade com a prevenção de acidentes ampliados.

O amadurecimento das idéias referidas ao desenvolvimento sustentável foi fundamental para que a atuação de ONGs e de redes de defesa transnacionais obtivesse o apoio da sociedade internacional. Foi fundamental, sobretudo, na transformação de mais uma ocorrência local em um fato social de contornos socioeconômico-políticos internacionais. A internacionalização da PAI viabilizou aquela atuação e a possibilidade de se destacar elementos de globalidade naquele evento local. Será o Princípio da Precaução que balizará, posteriormente, a defesa por instrumentos normativos eficientes para a prevenção de novos Bhopais. Em especial, em localidades receptoras de padrões poluidores e inadequados de produção, estocagem e transporte de substâncias químicas. Aperfeiçoavam-se as percepções e reflexões que construíram o Princípio do Poluidor Pagador, que traduzia o repúdio da sociedade internacional à fraude, ao embuste, à ilusão promovidos pelas empresas multinacionais com relação a seus processos produtivos. Foi a partir da constituição desses elos de diálogo, pressão e ativismo, que unem o acidente ao debate político internacional, que a indústria química passou a adotar, em todo o mundo, programas de atuação responsável ${ }^{14}$.

Aqueles agentes procuraram transformar os termos e a natureza do debate político internacional, criando, dessa forma, novos conceitos e linguagem. Percebe-se que os grupos sociais ajudam a transformar a prática da soberania nacional, a atuação das OIs, além do próprio sistema internacional. Quanto à linguagem e aos conceitos, observou-se que as redes influenciaram o estabelecimento da agenda política internacional - muitas vezes determinadas por comunidades de especialistas -, ao moldarem a questão da segurança química, tornando-a compreensível a públicos-alvo, atraindo a atenção e incenti- 


\section{O Local e o Global na Estrutura da Política Ambiental Internacional...}

vando a ação da sociedade. Trouxeram à tona do debate político novas idéias, discursos e normas, contribuindo para alterar as percepções dos Estados e demais atores sociais sobre suas próprias identidades, interesses, preferências e posições discursivas; concorrendo, ainda, para modificar procedimentos, políticas e comportamentos. As empresas multinacionais, neste caso, também exerceram influência sobre a norma negociada, uma vez que lhes interessava a definição de contornos adequados ao instrumento, que minimizassem custos e amenizassem deveres e obrigações, tanto quanto fosse possível.

Evidencia-se que a norma gerada tem caráter constitutivo porque determina uma nova realidade social tanto para a sociedade internacional, quanto para as empresas multinacionais do setor químico que tiveram que mudar seus padrões de relacionamento com a sociedade e com o meio ambiente. Quanto à linguagem, ainda, constata-se, nos vinte anos de amadurecimento da PAI, um aperfeiçoamento conceitual dos agentes sociais envolvidos, mas também dos próprios agentes políticos, alvo das estratégias de disseminação.

Esta visão mais social do ambiente internacional permite caracterizar o acidente químico de Bhopal como um fato social, construído a partir de redes cognitivas criadas por agentes sociais a fim de oferecer significado ao mundo material. A construção social do acidente é viabilizada pelo amadurecimento de uma conscientização ambiental (entre 1972 e 1992) ou pela anuência coletiva em torno do desenvolvimento sustentável e da segurança química. Defende-se que essa conscientização se intensificou, resultando em significativa mobilização social, a partir da repetição - primeiro nos países industrializados e, posteriormente, naqueles em via de desenvolvimento - daquele tipo de evento. Daí decorre que os mais influentes agentes de propagação das idéias enfocadas neste trabalho tenham sido as organizações da sociedade civil, novos atores sociais da cena internacional que contribuíram para oferecer o contorno social ao evento e para 
sintetizar aquelas idéias na norma gerada. Na adoção desse tipo de visão, é fundamental, por um lado, incorporar o contexto cultural e institucional à análise da construção social e normativa; e, por outro, recorrer à evolução cognitiva evidenciada na construção do acidente como um fato social. Por isso, recorreu-se à reconstrução da estrutura de idéias referidas ao meio ambiente e à segurança química. Merece destaque, também, nesse mundo social enfocado, os processos de aprendizagem de novas idéias e conceitos, entendidos como a adoção, por parte dos decisores, de novas interpretações da realidade, na medida em que estas são criadas e introduzidas no sistema político pelos agentes sociais. Nesse processo são selecionadas premissas epistêmicas e normativas, que se revelarão robustas conforme forem compartilhadas intersubjetivamente entre as instituições.

A linguagem é, sem dúvida, fonte de significados para a compreensão da gênese da norma. É a estrutura de interação discursiva que controla os significados sociais: os fatos institucionais somente adquirem sentido quando são considerados os contextos sociolingüísticos em que estão inseridos. Passa pela linguagem a investigação de como e por que determinadas idéias se tornam politicamente dominantes e são sintetizadas em normas constitutivas.

\section{Implicações Normativas Globais do Evento Local: A Construção Social da Convenção 174 da OlT}

Normas, identidades e interesses são mutuamente constitutivos. Isso porque as normas estão incrustadas em estruturas sociais e ideacionais que demarcam valores e intencionalidades coletivas. Para se compreender o processo de construção normativa, faz-se necessário recorrer à análise das ações de agentes relevantes e, também, das idéias defendidas naquele processo, além de localizar agentes e estrutura em contextos históricos específicos. As normas resultam em 


\section{O Local e o Global na Estrutura da Política}

Ambiental Internacional...

práticas; são a síntese das idéias em debate e das ações dos diferentes atores sociais. Indagar sobre que normas existem é indagar sobre que idéias prevaleceram, quem eram seus proponentes e a partir de que base material essas normas emanaram. Isso porque as normas não surgem em vácuos normativos ou institucionais. Surgem, outrossim, em contextos de efervescência ideacional em que prevalece a disputa pela prerrogativa de se determinar as características da norma constitutiva negociada. A linguagem e a estratégia de disseminação de conceitos são essenciais para a predominância de plataformas organizacionais específicas e para a conseqüente concretização de determinados projetos normativos. Afinal, "[n]ormas não surgem do nada. São ativamente construídas por agentes que têm noções consolidadas sobre que tipos de comportamentos são apropriados ou desejáveis na comunidade" (Finnemoree Sikkink, 1998:896). Assim, neste artigo, defende-se que não é possível prescindir do exame de um contexto ideacional e normativo mais amplo, em que se insere o acidente e em que se negocia a Convenção 174 da OIT. Tampouco é possível prescindir do exame da atuação dos empreendedores naquele contexto, uma vez que são esses agentes que chamam a atenção para determinadas questões às vezes aparentemente sem grande relevo para as relações internacionais - como um acidente e suas implicações sociais, políticas, jurídicas e econômicas.

O acidente químico de Bhopal adquiriu contornos sociais devido, em grande medida, à atuação de ativistas e da própria indústria que transforma seu discurso, assimilando a noção de responsabilidade social. Os ativistas não apenas participam da construção social do acidente, como também tentam ampliar as possibilidades de gênese de normas principalmente onde há lacuna institucional e normativa, como no caso observado - e, posteriormente, o escopo da mesma. As empresas multinacionais, por sua vez, também influenciam a definição dos contornos da norma a fim de tentar construir normas das quais possam beneficiar-se, quer pela definição mais amena de deveres e obrigações 
para com o meio ambiente e a saúde humana, quer pela determinação dos menores custos possíveis. É essencial, nesse sentido, perceber o caráter constitutivo das normas negociadas. Uma nova realidade delineia-se para a sociedade internacional e para as empresas multinacionais que deverão modificar seus padrões de relacionamento com aquela mesma sociedade e com o meio ambiente circundante.

Para tanto, utilizam linguagem que nomeia essas questões, oferecendo-lhes contornos sociais a partir de quadros cognitivos específicos. No caso enfocado, foi a partir desses quadros que as sociedades industrializadas perceberam o acidente de Bhopal como inaceitável e não passível de repetição. Bhopal não era um caso isolado, em uma terra distante, resultante de condiçõos e fatores endêmicos de países em desenvolvimento. A construção de percepções é componente essencial das estratégias políticas daqueles empreendedores, uma vez que, a partir dos entendimentos instituídos, atingem o público e criam novas formas de se compreender a realidade. Na construção daqueles moldes de conhecimento, os empreendedores de norma estão sempre diante de compreensões alternativas quanto ao que é apropriado e ao que interessa a suas organizações. Assim, é possível afirmar que as normas não surgem de vazios institucionais, mas de espaços em que ocorre o embate político entre diversas percepções sobre qual seria a norma mais adequada a se criar. A nova norma emerge de uma estrutura ideacional, institucional e normativa: as idéias, as instituições e as normas que a antecederam ditam os padrões do que é apropriado ou não.

Os empreendedores de norma, sem dúvida, necessitam de plataformas organizacionais a partir das quais promoverão determinadas percepções sobre as normas a serem adotadas. Nem sempre, no entanto, esses empreendedores atuam por meio de organizações da sociedade civil ou de redes de ativistas, compostas por essas organizações. Muitas vezes, atuam em organismos internacionais que, ainda assim, contam com propósitos e agendas mais abrangentes que a pro- 


\section{O Local e o Global na Estrutura da Política \\ Ambiental Internacional...}

moção específica de normas ${ }^{15}$. De qualquer forma, seja qual for a organização ou a plataforma adotada, o empreendedor não pode prescindir do apoio dos atores estatais - entes que negociam e firmam as normas - para endossar a proposta normativa apresentada ou, ainda, para incluir, nas agendas governamentais, a adesão posterior àquela norma. No máximo, podem persuadi-los a avaliar e, posteriormente, adotar determinada opção normativa. Esse processo de aprendizado institucional não está baseado em princípios externos coercitivos, mas em elementos de convencimento sobre a melhor alternativa de política a se adotar. A formação das identidades e dos interesses dos atores estatais pode ser verificada somente nesse contexto ideacional, institucional e normativo. Tal é o caso, claramente, da negociação da Convenção 174 da OIT.

Neste trabalho, não se pensou a ligação entre o acidente e a norma de forma unívoca. Tanto é assim que se teve o cuidado de atentar para o contexto estrutural mais amplo e para a ocorrência de outros acidentes. Isso porque os acidentes contribuíram para a ampliação da consciência global quanto aos perigos associados à produção de substâncias químicas, para a reestruturação da indústria química em todo o mundo, bem como para a negociação de diversas normas ambientais. Optou-se, no entanto, a fim de melhor estudar os processos de construção social nas RI, em especial na área ambiental, por tratar de maneira mais específica essa questão. Em outras palavras, optou-se por analisar a construção normativa nas RI a partir da relação entre o acidente de Bhopal e a Convenção 174 da OIT.

O impacto do acidente - em termos de perdas humanas e de conscientização quanto aos riscos associados àquelas atividades industriais e à necessidade de se gerarem informações fidedignas - serviu para pavimentar o caminho para a adoção de medidas que pudessem evitar a reincidência de eventos daquela magnitude. No âmbito internacional, foi negociada a Convenção 174 da OIT para a prevenção de acidentes industriais maiores. Em 1993, esta Convenção foi assinada 
e conta, hoje, com onze ratificações ${ }^{16}$ dos seguintes países: Albânia, Arábia Saudita, Armênia, Bélgica, Brasil, Colômbia, Estônia, Líbano, Holanda, Suécia e Zimbábue. De acordo com o item 2 do Artigo 24 daquele instrumento internacional, a entrada em vigor do mesmo ocorreu doze meses após a data em que se registraram as ratificações de dois membros da OIT. A Convenção 174 é um instrumento essencialmente preventivo, cujo esboço reflete a consolidação, na PAI, do princípio da precaução. Insta aos países que elaborem legislações nacionais mais rígidas para a prevenção de acidentes ampliados.

Por que a OIT passa a ser o fórum para a negociação de uma norma preventiva de novos Bhopais e qual a relação da Organização com o ambiente social internacional analisado? Desde a Conferência de Estocolmo, e esse foi um de seus objetivos, pretendia-se promover uma abordagem mais coordenada para o tratamento das questões ligadas ao meio ambiente. Constituiu-se, naquela Conferência, o PNUMA - aliás, um de seus resultados mais duradouros. No entanto, com a efervescência e o amadurecimento da consciência ambiental mundial e com a conseqüente ampliação e aprofundamento da cooperação internacional nessa área, faltava àquele Programa das Nações Unidas o peso institucional exigido para a coordenação efetiva das agendas ambientais dentro do Sistema da ONU. Se a cooperação internacional na área de fato se intensificou, tornaram-se evidentes, também, várias lacunas institucionais no âmbito da ONU. A coordenação política é um tema que extrapola a área ambiental; a dificuldade de se empreenderem ações cooperativas e complementares nesse setor, entretanto, é emblemática da realidade de superposição de funções e de desperdício de esforços em que se tornou a cooperação funcional no Sistema da ONU. Ainda assim, é preciso destacar que essa realidade está presente nas considerações de reforma deste Sistema. A proposta de 1997 do secretário-geral de reforma administrativa da Organização estabelece, entre várias prioridades, a ampliação da coordenação de ações no Sistema. 


\section{O Local e o Global na Estrutura da Política}

Ambiental Internacional...

A Agenda 21 (1992), em seu capítulo 19, incorpora também propostas destinadas a reforçar as ações coordenadas que promovem a segurança química a níveis internacional e nacional. A colaboração na área de segurança química tem impulso considerável a partir da aprovação daquele documento com a constituição, em 1980, do PISQ. Outra expressão da coordenação das políticas, no Sistema, para essa área, é o Inter-Organization Programme for the Sound Management of Chemicals (IOMC). Estabelecido, em 1995, este programa objetiva fortalecer a cooperação entre os organismos internacionais envolvidos no campo da segurança química, possibilitando, também, o incremento dos programas de cada organismo para esse campo. Promove a coordenação de políticas e atividades, desenvolvidas conjunta ou separadamente, a fim de se alcançar padrões sustentáveis de utilização das substâncias químicas em relação à saúde humana e ao meio ambiente. Está composto pela OIT, pela FAO, pelo PNUMA, pela Organização das Nações Unidas para o Desenvolvimento Industrial (em inglês, UNIDO), pela Organização para Cooperação e Desenvolvimento Econômico (OCDE) e pela OMS. Em 1997, o Instituto das Nações Unidas para o Treinamento e a Pesquisa (em inglês, UNITAR) associou-se ao Programa, que conta, ainda, com a participação, como observadores, do Programa das Nações Unidas para o Desenvolvimento (PNUD) e do Banco Mundial.

Esses seriam os núcleos da cooperação e da colaboração internacional para o manejo ambientalmente saudável dos produtos químicos. Na verdade, a possibilidade de se delinearem planos de ação conjunta entre o PNUMA, a OIT e a OMS já havia sido identificada pelo Comitê Preparatório da Rio-92. Este Comitê convidou o PISQ a apontar mecanismos intergovernamentais para a avaliação de risco e o gerenciamento de substâncias químicas. Assim é que se realiza, em Londres, em dezembro de 1991, uma reunião de especialistas a fim de conceber uma estratégia internacional e uma proposta para o estabelecimento de um mecanismo intergovernamental. Dessa reunião, re- 
sultou uma recomendação do Fórum Intergovernamental de Segurança Química (FISQ) que se transformou em um instrumento amplo de cooperação e de fomento, voltado para o desenvolvimento de estratégias e parcerias entre os Estados, as OIs e os organismos não-governamentais na avaliação dos riscos, dos pontos de vista ecológico e humano, e na gestão segura dos produtos químicos.

Tanto as diretrizes preconizadas pelo capítulo 19 da Agenda 21 (1992) quanto os debates ocorridos no FISQ englobam questões relacionadas a estratégias de gerenciamento químico, classificação e rotulagem, fortalecimento institucional e procedimentos para a troca de informações seguras sobre o risco de substâncias químicas, estoques obsoletos de pesticidas, sistemas nacionais para a prevenção de acidentes industriais ampliados e para o preparo e a resposta a emergências, inventário de emissões, prevenção de tráfico ilegal de produtos tóxicos e perigosos, harmonização de princípios para a avaliação de risco, classificação e código de conduta para a distribuição e o uso de pesticidas. Diversos tratados internacionais resultaram da discussão e da institucionalização política, em âmbito internacional, entre os quais a Convenção 174 da OIT.

Percebe-se, pela enumeração dessa diversidade de mecanismos, que as OIs desempenham papel atuante na área da segurança química. Ao longo do tempo, a OIT, entre essas OIs, tornou-se uma agência líder na discussão internacional desses temas, juntamente com o PNUMA e a OMS, cada qual, em seu campo de atuação, procurando padronizar e regulamentar a utilização de substâncias químicas. A OIT é uma agência especializada da ONU, fundada em 1919 e assimilada pelo Sistema da ONU em 1946. Objetiva a promoção da justiça social e o reconhecimento, a nível internacional, de direitos laborais e humanos. Formula padrões internacionais de trabalho, sob a forma de Convenções e Recomendações. Em decorrência da sua constituição, em que cada Estado-membro é representado por delegados do governo, do setor patronal e de sindicatos, a OIT tornou-se permeável ao ambiente social 


\section{O Local e o Global na Estrutura da Política Ambiental Internacional...}

internacional em que as OIs estão inseridas. É preciso destacar, nesse sentido, o processo de aprendizagem a que estão submetidos os decisores de organizações internacionais como a OIT. Esse processo é o que conecta o organismo à estrutura ideacional analisada neste trabalho. As pressões externas para que esses organismos utilizem sua autoridade racional-legal (Barnett e Finnemore, 1999), fonte criadora de normas e, conseqüentemente, de conhecimento, desencadeiam processos de aprendizagem que, por sua vez, mobilizam as burocracias no estabelecimento de tarefas comuns, na definição de novas categorias de atores, no delineamento de novos interesses e, sobretudo, na determinação de padrões de organização política.

Especificamente quanto ao acidente de Bhopal, na sessão número 229 do Conselho de Administração, ocorrida entre 25 de fevereiro e $1^{\circ}$ de março de 1985, o diretor-geral da OIT, Sr. Francis Blanchard, apresentou o relatório intitulado Issues of Concern to the ILO Arising out of Recent Industrial Accidents in Bhopal and Elsewhere. Este relatório oferece um panorama das pressões externas, vindas de ativistas políticos, para se prevenir ocorrências como aquela de Bhopal.

"Desde a tragédia de Bhopal, o Escritório vem recebendo várias cartas, conclamando à adoção de medidas por parte da OIT. Receberam-se duas representações da International Confederation of Free Trade Unions (ICFTU) e da World Federation of Trade Unions (WFTU). A ICFTU propôs que se realizasse uma investigação independente das causas do desastre, em consonância com a Declaração Tripartite da OIT sobre Multinacionais; além disso, que se organizasse, em caráter de urgência, uma reunião internacional tripartite de especialistas a fim de examinar os perigos a que estão sujeitos trabalhadores e comunidades vizinhas às fábricas que produzem substâncias químicas e, posteriormente, de desenvolver padrões apropriados. A WFTU também propôs que a OIT investigasse, em cooperação com o governo da Índia e o movimento sindical daquele país, as causas do acidente e a responsabilidade da Union Carbide no que se refere à observância de padrões de segurança. Ademais, a OIT deveria examinar os aspectos relacionados à segurança das tecnologias utilizadas na manufatura de produtos químicos perigosos, como os pesticidas, em cooperação com a OMS, o PNUMA e ou- 
tras agências da ONU [...]. A OIT foi informada, pela International Federation of Chemical, Energy and General Workers' Unions, das propostas enviadas ao governo indiano para que se apontasse uma comissão independente de inquérito, composta de representantes da OIT e da OMS, para investigar o acidente. A OIT recebeu, também, comunicação do Central Council of Bulgarian Trade Unions referindo-se aos aspectos corporativos do acidente e demandando intervenção apropriada da OIT. O Escritório recebeu um grande número de petições de membros do grupo francês Réseau Solidarité com o mesmo tipo de conteúdo" (Governing Body/International Labour Organization, 1985:3).

Nesse relatório, o diretor-geral insiste em lembrar que Bhopal não é um evento isolado, enumerando outros acidentes semelhantes (Flixborough, Inglaterra, em 1974; Seveso, Itália, em 1976; Cidade do México, México, em 1984) que também deveriam ser considerados na elaboração de medidas preventivas de acidentes ampliados. A partir das discussões sobre o desastre de Bhopal, a Conferência Internacional do Trabalho adotou, em junho de 1985, uma resolução sobre a promoção de medidas contra os riscos de acidentes, ocasionados pela utilização de substâncias e procedimentos perigosos por parte da indústria química. Em decorrência dessa resolução, a OIT deu início a uma série de ações, como: (1) a organização de reuniões ad-hoc sobre o tema; (2) a preparação de um manual sobre o controle de riscos de acidentes maiores; (3) a elaboração de um repertório de recomendações práticas sobre a prevenção de acidentes industriais maiores; (4) a organização de seminários nacionais e regionais sobre o tema; (5) o oferecimento de assessorias técnicas para o estabelecimento de sistemas nacionais de controle de risco de acidente; (6) o desenho e a execução de projetos de cooperação técnica. Negociou-se, posteriormente, a Convenção 170 sobre substâncias químicas e elaborou-se e aprovou-se a Recomendação 177 sobre substâncias químicas, ambas no ano de 1990.

Os desdobramentos do acidente de Bhopal, em termos de perdas humanas, de passivo ambiental, de ativismo político, demonstraram 


\section{O Local e o Global na Estrutura da Política Ambiental Internacional...}

para as nações e, sobretudo, para as burocracias detentoras de autoridade racional-legal, que seria necessário coordenar esforços a níveis nacional e internacional para garantir a proteção aos trabalhadores, às populações e ao meio ambiente. No âmbito da OIT, foi instituída em 1992 pela Conferência Internacional do Trabalho a Comissão para a Prevenção de Desastres Industriais. A primeira discussão, com vistas à elaboração de um instrumento internacional para a prevenção de acidentes industriais ampliados, teve lugar na septuagésima nona reunião daquela Conferência, ocorrida em Genebra, em 1992. Naquela ocasião, aprovaram-se propostas para a elaboração de uma Convenção e uma Recomendação relativas à prevenção de acidentes industriais ampliados. Concordou-se em inscrever a segunda discussão sobre a adoção daqueles instrumentos na próxima reunião ordinária da Conferência. Nesse ínterim, e de acordo com o artigo 39 do Regulamento da Conferência, o Escritório Internacional do Trabalho preparou e enviou aos governos dos Estados-membros um informe - Informe IV (1), intitulado "Prevenção de Acidentes Industriais Maiores" - em que constava um projeto de Convenção e um de Recomendação. Cinqüienta e sete Estados enviaram emendas ou observações àquelas propostas, sendo que 36 declararam haver consultado as organizações mais representativas de empregadores e trabalhadores. Essas propostas refletiam os interesses e as identidades dos atores estatais, e aquelas emendas serviram de sustentação à discussão sobre as propostas de texto que viria a se tornar a Convenção 174.

O texto da Convenção foi aprovado na reunião subseqüente da Conferência. Era a síntese do processo de construção social que culmina com a transformação de Bhopal em um fato social relevante para a PAI. Bhopal expressava, em grande medida, os anseios das comunidades afetadas naquela localidade e em outras tantas que já haviam sido acometidas por tragédias semelhantes nos vinte anos de amadurecimento de uma consciência ambiental global. Visava-se, com a negociação de uma norma internacional, no âmbito da OIT, prevenir 
novas ocorrências, sobretudo com as dimensões de Bhopal, e minimizar os riscos e os efeitos de novos acidentes ampliados; além disso, era imprescindível definir a responsabilidade de empregadores, de autoridades competentes com relação ao preparo, em caso de emergências, dos Estados exportadores; bem como o direito e as obrigações dos trabalhadores e de seus representantes.

\section{Considerações Finais}

Teoricamente, a análise proposta por este estudo partiu de uma articulação de conceitos do construtivismo para observar os laços que unem o acidente de Bhopal a uma estrutura ideacional, normativa e institucional mais ampla, referente ao desenvolvimento sustentável. Essa articulação pode ser visualizada, esquematicamente, a seguir.

Essa articulação conceitual foi útil para refletir sobre a relação de co-constituição entre estrutura e eventos nas relações internacionais. Se, por um lado, os agentes transformam o evento material em fato social, a partir do amadurecimento das idéias, normas, instituições que compõem aquela estrutura ou de uma evolução cognitiva; por outro, aquela estrutura é transformada por esse processo de construção social, em que novos conceitos, novas categorias de direitos e de atores são constituídos. Essa relação de co-constituição passou a ser percebida por meio da relação entre o local e o global na Política Ambiental Internacional. Mais precisamente, a ilustração esquematiza a forma como parte dos protestos locais se consolidaram como uma norma global, uma vez que se enfocaram apenas os impactos normativos para a segurança química verificados em um organismo internacional que trata da regulamentação na área do trabalho.

Os ativistas políticos ou empreendedores de norma, reunidos nas redes de defesa transnacional, são acionados na medida em que, após a ocorrência do evento local, revelam-se lacunas normativas ou lapsos de exercício de soberania estatal. Os cidadãos afetados, forçosamen- 
O Local e o Global na Estrutura da Política Ambiental Internacional..

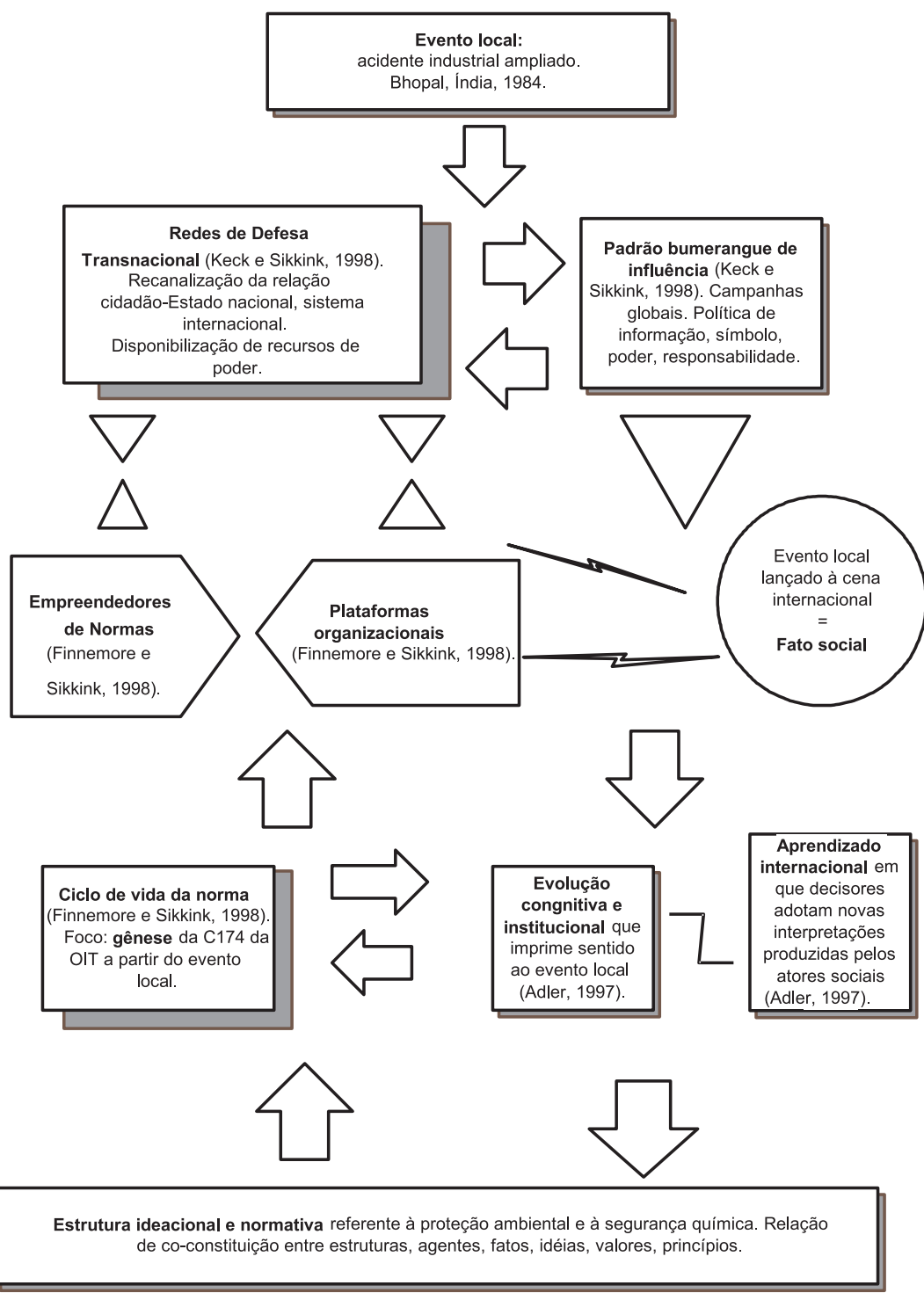


te, tiveram que recorrer a essas redes a fim de aceder aos recursos de poder disponíveis no SI, chamando atenção da sociedade internacional para o acidente químico que os havia afetado. O canal estatal encontrava-se bloqueado, e uma resposta imediata à tragédia urgia. Nesse processo de recanalização entre cidadãos, Estados e SI, ganham relevo as campanhas e a linguagem de persuasão, concebidas pelas redes. Desencadeia-se um embate entre plataformas organizacionais a fim de determinar as diretrizes do processo de aprendizagem acerca daquele evento e, sobretudo, a síntese que comporia uma norma que visasse prevenir aquele tipo de ocorrência.

Esse processo de aprendizagem abarcou toda a sociedade internacional; entretanto, neste trabalho, enfocou-se apenas a forma como a OIT teve sua autoridade racional-legal pressionada por esse processo de aprendizagem, no caso institucional. Na verdade, procurou-se enfatizar que, naquele processo de evolução cognitiva, que vai da Conferência de Estocolmo de 1972 à Conferência do Rio de 1992, o tema da segurança química consolidou-se como um item da agenda política da PAI. A Convenção 174 foi negociada sob a sombra da tragédia de Bhopal, mas é o resultado do amadurecimento ideacional, normativo e institucional abordado neste trabalho; da mesma forma, o processo de construção social de Bhopal somente foi possível por conta desse amadurecimento. À Política Ambiental Internacional, após a ocorrência do evento local e da negociação da norma global, acrescentaram-se novas categorias de atores, conceitos e procedimentos.

Em última instância, o processo de construção enfocado na área ambiental lança luz sobre novas fontes normativas e, sobretudo, sobre novas formas de exercício da política internacional, em que o conceito de soberania, baseado na territorialidade, é necessariamente reavaliado. 


\section{O Local e o Global na Estrutura da Política Ambiental Internacional...}

\section{Notas}

1. A maioria das vítimas vivia em favelas ao redor da fábrica. Quando ocorreu o acidente, ao soar o alarme de emergência, os moradores não imaginavam que se tratava de uma catástrofe. Isso porque a mesma sirene era usada para anunciar mudança de turnos de trabalho na planta (Cummings, 1986:110). Para uma investigação jornalística consistente sobre o acidente e suas consequiências, consultar Lapierre e Moro (2002).

2. Segundo dados do relatório do Greenpeace, intitulado Crimes Ambientais Corporativos (disponível em: <http://www.greenpeace.org.br/toxicos/pdf/corporate_crimes.pdf $>$ ), a cada dois dias, uma pessoa morre, ainda em conseqüência daquele evento. As principais doenças que afetam a população são: fibrose pulmonar, problemas de visão, bronquite asmática, tuberculose, falta de ar, perda de apetite, fortes dores no corpo, ciclos menstruais irregulares, febre recorrente, tosse persistente, desordens neurológicas, fadiga, cansaço, ansiedade e depressão. Ainda segundo o relatório do Greenpeace, muitas das crianças que nasceram após o desastre enfrentam problemas de crescimento e distúrbios hormonais. Verificam-se, ainda, aberrações genéticas na população exposta que indicam grande probabilidade de má-formação congênita nas próximas gerações.

3. Há uma discussão a respeito da adequação do termo "acidente maior", adotado internacionalmente pela Diretiva de Seveso ( $<$ http://www.europa.eu.int/ eur-lex/pt/>), pela Convenção 174 da Organização Internacional do Trabalho (OIT) (<http://www.ilo.org/ilolex/cgi-lex/convde.pl?C174>) e pela Convenção sobre os Efeitos Transfronteiriços de Acidentes Industriais (<http://www. unece.org/env/teia/text.htm>). No Brasil, optou-se pelo conceito de acidente ampliado para designar "eventos agudos, como explosões, incêndios e emissões nas atividades de produção, isolados ou combinados, envolvendo uma ou mais substâncias perigosas com potencial para causar simultaneamente múltiplos danos, sociais, ambientais e à saúde física e mental dos seres humanos expostos" (Freitas, Porto e Machado, 2000:28) por se considerar que este expressa mais adequadamente a possibilidade de ampliação espacial e temporal das conseqüências desses eventos para a saúde humana e para o meio ambiente.

4. Para abordagem tradicional do tema ambiental pela literatura de regimes, ver Young (1989).

5. Sobre o tema da causalidade das idéias, ver Yee (1996).

6. A caracterização do acidente como um fato social tem inspiração na obra de Searle (1995). 


\section{Aletheia de Almeida Machado}

7. A segurança química refere-se à prevenção dos efeitos adversos, para a saúde humana e para o meio ambiente, decorrentes da produção, armazenagem, transporte, manuseio e descarte de produtos químicos. Acredita-se na existência de quase 10 milhões de substâncias químicas das quais cerca de 100 mil são de uso difundido. Dessas, apenas uma parte reduzida foi submetida à avaliação de risco. Sobre o tema "Saúde e Ambiente", ver o site da Organização Pan-Americana da Saúde (OPAS), disponível em <http://www.opas.org.br>.

8. Para uma abordagem sócio-histórica da evolução do ambientalismo global, ver McCormick (1989).

9. Conhecida como Rio- 92 ou pela sigla UNCED, que substitui a nomenclatura inglesa United Nations Conference on Environment and Development.

10. A globalização da temática ambiental, na verdade, é um processo contínuo de construção ideacional do qual merecem destaque dois outros marcos institucionais: a Sessão Especial da Assembléia Geral das Nações Unidas para revisão e avaliação da implementação da Agenda 21 (Nova Iorque, junho de 1997), em seguimento à Rio-92, a Rio+5; e a Conferência Mundial das Nações Unidas sobre Desenvolvimento Sustentável (a United Nations World Summit on Sustainable Development - WSSD), ocorrida em 2002, em Johanesburgo - a Rio+10. Em ambos os eventos, há uma preocupação generalizada em resgatar e realimentar o momentum global vivido pela temática ambiental, com a realização da Conferência do Rio de Janeiro de 1992. Não apenas isso: é clara a intenção dos líderes mundiais e da sociedade civil global de vocalizar uma mensagem de ativismo e de produção de resultados no que se refere à assimilação das diretrizes contidas na Agenda 21 (1992) e à ratificação de acordos essenciais para a construção normativa da área - o Protocolo de Kyoto, em especial.

11. A noção de futuridade abarca as preocupações com os efeitos futuros de iniciativas políticas ou normativas, na área ambiental. Mais especificamente, trata-se da preocupação com as gerações futuras que corrobora a idéia de que é preciso fortalecer o princípio da precaução (Soares, 2003:37-38).

12. Ver Cummings (1986), Rosencranz (1988), Sax (1985)e Abrahame Abraham (1991).

13. Para as diversas estratégias adotadas pelos movimentos sociais em repúdio à tragédia de Bhopal, ver <http://www.bhopal.net> e o Report of the International Confederation of Free Trade Unions (ICFTU) Mission to Study the Causes and Effects of the Methyl Isocyanate Gas Leak at the Union Carbide Pesticide Plant in Bhopal, India, on December 2nd/3rd, 1984, disponível em $<$ http://www.bhopal.net/documentlibrary/unionreport1985.html>. Ver ainda IOCU (1985). 


\section{O Local e o Global na Estrutura da Política Ambiental Internacional...}

14. Os embates entre ativistas políticos e empresas mundiais mantêm-se. A demanda do Greenpeace pela construção de mecanismos normativos que tratem de crimes corporativos e não apenas de atuação responsável pode ser vista em $<$ http://www.greenpeace.org.br/toxicos/pdf/corporate_crimes.pdf $>$.

15. Nem todos os organismos internacionais estão desenhados para a promoção de normas, mas alguns, como o Banco Mundial, contam com a vantagem de dispor de recursos e de poder para exercer pressão em prol de determinadas opções normativas (Finnemore e Sikkink, 1998:900).

16. Para lista atualizada das ratificações a essa norma, ver $<$ http://www.ilo. org/ilolex/cgi-lex/ratifce.pl?C174>.

\section{Referências Bibliográficas}

ABRAHAM, C. M. e ABRAHAM, S. (1991), "The Bhopal Case and the Development of Environmental Law in India". International and Comparative Law Quartely, vol. 40, pp. 334-365.

ADLER, E. (1997), "Seizing the Middle Ground: Constructivism in World Politics". European Journal of International Relations, vol. 3, n 3, pp. 319-363.

AGENDA 21. (1992), disponível em <http://www.mma.gov.br/port/se/agen21/ index.cfm>.

BARNETT, Michael e FINNEMORE, Martha. (1999), “The Politics, Power, and Pathologies of International Organizations". International Organization, vol. 53, n 4, pp. 699-732.

CARSON, Rachel. (2002) [1962], Silent Spring. Boston, Mariner Books.

COMISSÃO MUNDIAL SOBRE MEIO AMBIENTE E DESENVOLVIMENTO. (1991), Nosso Futuro Comum. Rio de Janeiro, Editora FGV.

CONFERÊNCIA DAS NAÇÕES UNIDAS SOBRE MEIO AMBIENTE E DESENVOLVIMENTO. Agenda 21. Disponível em <http://www.mma.gov. br/index.php?ido=conteudo.monta\&idEstrutura $=18 \&$ idConteudo=577> . 


\section{Aletheia de Almeida Machado}

CUMMINGS, S. (1986), "International Mass Tort Litigation: Forum Non Conveniens and the Adequate Alternative Forum in Light of the Bhopal Disaster". Georgia Journal of International and Comparative Law. Atlanta, vol.16, $\mathrm{n}^{\circ} 1$, pp. 109-166.

DECLARAÇÃO DO RIO. (1992), disponível em <http://www.mma.gov.br/index.php?ido $=$ conteudo.monta\&idEstrutura $=18 \&$ idConteudo $=576>$.

FINNEMORE, M. e SIKKINK, K. (1998), “International Norm Dynamics and Political Change”. International Organization, vol. 52, nº 4, pp. 887-917.

FREITAS, C. M., PORTO, M. F. S. e MACHADO, J. M. H. (2000), Acidentes Industriais Ampliados. Desafios e Perspectivas para o Controle e a Prevenção. Rio de Janeiro, Editora Fiocruz.

GEO-2003 - GLOBAL ENVIRONMENT OUTLOOK. (2003), "Past, Present and Future Perspectives". Capítulos 2-9. Disponível em <http://www.grida.no/geo/geo3>.

GOVERNING BODY/INTERNATIONAL LABOUR ORGANIZATION. (1985), Report of the Director General. Third Supplementary Report. Issues of Concern to the ILO Arising out of Recent Industrial Accidents in Bhopal and Elsewhere. GB.229/18/9. $229^{\text {th }}$ Session. Genebra, 25 de fevereiro a $1^{\circ}$ de março.

GREENE, O. (1997), “Environmental Issues”, in J. Baylis e S. Smith, The Globalization of World Politics. An Introduction to International Relations. New York, Oxford University Press.

HARDIN, Garrett. (1968), “The Tragedy of the Commons”. Science, n' 162, pp. 1.243-1.248.

HURRELL, A. (1995), "International Political Theory and the Global Environment”, in K. Booth e S. Smith (eds.), International Relations Theory Today. University Park, The Pennsylvania State University Press, pp. 129-153.

IOCU - INTERNATIONAL ORGANIZATION OF CONSUMERS UNIONS. (1985), The Lessons of Bhopal. A Community Action Resource Manual on Hazardous Technologies. Penang, IOCU Regional Office for Asia and the Pacific.

KECK, M. e SIKKINK, K. (1998), Activists beyond Borders: Advocacy Networks in International Politics. Ithaca, Cornell University Press.

LAPIERRE, D. e MORO, J. (2002), Five Past Midnight in Bhopal. The Epic Story of the World's Deadliest Industrial Disaster. New York, Warner Books. 


\section{O Local e o Global na Estrutura da Política \\ Ambiental Internacional...}

LITFIN, K. T. (1999), "Environmental Security in the Coming Century", in T. V. Paul e J. A. Hall, International Order and the Future of World Politics. Cambridge, Cambridge University Press, pp. 329-330.

McCORMICK, J. (1989), Reclaiming Paradise. The Global Environmental Movement. Indianapolis, Indiana University Press.

MEADOWS, Donella H., MEADOWS, Dennis L., RANDERS, Jørgen e BEHRENS III, William W. (1972), The Limits to Growth. New York, University Books.

ROSENCRANZ, A. (1988), "The Twist and Turns of the Bhopal Lawsuits". Environmental Policy and Law, vol. 18, nº 3, pp. 81-83.

RUGGIE, J. G. (1998), "What Makes the World Hang Together? Neo-Utilitarianism and the Social Constructivist Challenge". International Organization, vol. $52, \mathrm{n}^{\circ} 4$, pp. 855-886.

SAX, Joseph L. (1985), "L'Affaire Bhopal devant les Tribunaux Américains. Forum non Conveniens". Revue Juridique de L'Environnement, vol. 4, $\mathrm{n}^{\circ} 4$, pp. 413-419.

SEARLE, John R. (1995), The Construction of Social Reality. New York, Free Press.

SHAW, Karena. (2004), "The Global/Local Politics of the Great Bear Rainforest”. Environmental Politics, vol. 13, nº 2, pp. 373-392.

SOARES, G. F. S. (2003), Direito Internacional do Meio Ambiente. Emergência, Obrigações e Responsabilidades. São Paulo, Atlas.

TAVARES, R. N. (1999), As Organizações Não-Governamentais nas Nações Unidas. Brasília, Instituto Rio Branco/Fundação Alexandre Gusmão/Centro de Estudos Estratégicos, pp. 95-110.

WEIR, D. e ABRAHAM, M. (1985), "Bhopal without End". Consumer Interpol Focus, no 12, pp. 1-10.

YEE, Albert S. (1996), “The Causal Effects of Ideas on Policies". International Organization, Cambridge, vol. 50, nº 1, pp. 69-108.

YOUNG, O. R. (1989), International Cooperation. Building Regimes for Natural Resources and the Environment. Ithaca, Cornell University Press. 


\section{Resumo}

\section{O Local e o Global na Estrutura da Política Ambiental Internacional: A Construção Social do Acidente Químico Ampliado de Bhopal e da Convenção 174 da OIT}

Neste artigo, adota-se a abordagem construtivista das Relações Internacionais (RI) para analisar o impacto normativo internacional do acidente químico de Bhopal, privilegiando-se o papel constitutivo da ação humana na Política Ambiental Internacional (PAI). Emprega-se articulação de conceitos construtivistas, útil na visualização da estrutura em que está inserido o evento local e, também, do processo de construção social tanto do evento quanto da norma internacional que precipitou.O pressuposto é o de que prevalece a co-constituição entre estruturas e agentes - responsáveis pela construção social do evento - e de que, portanto, não se pode prescindir desses elementos, tampouco dos elos que os unem. Almeja-se, por um lado, compreender a maneira pela qual o evento local é construído socialmente, tendo por referência a estrutura de idéias e de normas, referidas à proteção ambiental e ao desenvolvimento sustentável; e, por outro, como a ocorrência local gera impactos políticos, sociais e normativos em nível global. Assim, evidenciam-se elementos de globalidade, pertencentes ao evento local, sobretudo quando se verifica um processo de amadurecimento ideacional e normativo que tem como marcos políticos a Conferência de Estocolmo sobre o Meio Ambiente Humano de 1972 e a Conferência das Nações Unidas sobre Desenvolvimento e Meio Ambiente, ocorrida no Rio de Janeiro, em 1992. Assim, destaca-se o contexto cultural e institucional da cena ambiental como um todo, evidenciando-se o veio condutor do processo de construção social enfocado: a relação local/global na área ambiental. Focaliza-se, também, o papel da Organização Internacional do Trabalho (OIT) como agência líder na discussão internacional da segurança química a fim de indicar por que a construção normativa enfocada se verifica no fórum daquela Organização Internacional (OI).

Palavras-chave: Relações Internacionais - Política Ambiental Internacional (PAI) - Construtivismo - Bhopal- Convenção 174 da OIT - Relação Local/Global 


\section{Abstract}

\section{The Local and the Global in the International Environmental Politics Structure: The Social Construction of the Bhopal Major Chemical Accident and the ILO Convention 174}

The present article utilizes the constructivist approach of International Relations (IR) to analyze the international normative impact of the Bhopal chemical accident, focusing on the constitutive role of the human action on the International Environmental Politics (IEP). It adopts an articulation of constructivist concepts, useful to visualize the structure in which the local event is embedded, as well as the social construction process of either the event and the international norm launched. The assumption is that a co-constitution relation between structure and agents, who are responsible for the social construction of the event, is preponderant and that, consequently, it is impossible to exclude these elements or their connecting links from the analysis. The article aims at understanding, on the one hand, the way in which the event is socially constructed, referring to the ideational and normative structure of environmental protection and sustainable development; and, on the other, how the local event produces political, social and normative impact at international level. As a result, the global features of local events become evident, specially considering the ideational and normative fulfillment of an environment consciousness, whose political milestones are the Stockholm 1972 United Nations Conference on the Human Environment and the 1992 United Nations Conference on Environment and Development, held in Rio de Janeiro. Therefore, the article emphasizes the cultural and institutional environmental context as whole, pointing out the local/global relationship. It also focuses on the role of the International Labour Organization (ILO) as a leader agency in the chemical safety field, in an attempt to indicate why the normative construction process has taken place on the forum of that International Organization (IO).

Key words: International Relations - International Environmental Politics (IEP) - Constructivism - Bhopal - ILO Convention 174 - Local/Global Relations 